\title{
A Thematic Analysis of Hawthorne's The Scarlet Letter
}

\author{
Parvin Ghasemi \\ Department of Foreign Languages and Linguistics, Faculty of Literature and \\ Humanities, Shiraz University, Pardis Eram, Shiraz 71944, Iran \\ e-mail: pghasemi2000@yahoo.com,pghasemi@rose.shirazu.ac.ir \\ Pyeaam Abbasi \\ Department of English, Faculty of Foreign Languages, Isfahan University, \\ Azadi Square, Boulevard of Daneshga, Isfahan, Iran \\ e-mail: pyeaam77@yahoo.co.uk
}

\begin{abstract}
The Scarlet Letter is yet another story of the never-ending conflict of individuals versus society in which the recurrent theme of appearance versus reality is central and woven into different elements of the novel. The significance of this theme lies in the fact that it is adopted by both the Puritan Culture to subjugate its members and hide the truth, and by a protagonist who claims a new identity and violates the Puritanical codes. This is traceable in two major binary oppositions elaborated in this paper as: Society / Individual; and Religion / Love with a look at the two characters of Dimmesdale / Hester and the two colours of Sable / Gules. This paper is an attempt to show how these binary oppositions work, throughout the novel, to stress appearance as a tool for fixing Puritanical codes, and reality as a tool for constructing new ones.
\end{abstract}

Key words: appearance, reality, society, Puritan Culture, individual, religion, love, sable, gules

The never-ending struggle of individual versus society is a dominant theme that has appeared in many literary masterpieces. To this The Scarlet Letter, the climax of Hawthorne's corpus is no exception. The conflict between social and individual values is stressed through the appearanceversus-reality theme by which Hawthorne intends to project an unresolved tension that satisfies the purpose of obscuring the truth. The individual values represented by characters like Tess, Winston Smith and Hester are symbolic of those values not in line with the public ones; characters that rebel to displace appearance represented by 'sable' are characters represented by the 'scarlet' reality. 
The Scarlet Letter, as a tale of a war between the Puritanical Culture and a member who violates a Puritanical code, weaves the appearanceversus-reality theme into the very structure of its elements. What Hawthorne implements is the dramatization of the tension to reconsider the use of terms such as love and religion. Hawthorne creates the theme of appearance-versus-reality represented by the characters to launch his attack on Puritanism. The duality of appearance versus reality is best shown when the reader finds no hope of reconciling a single character's private life with that of the public. In discussing the two kinds of man in the society, Marx (1975) as .... member of civil society is taken to be the real man" for he is in "his ... sensuous, individual ... existence," while "political man is ... abstract, artificial man, man as ... moral person" (p. 234). ${ }^{1}$ Hawthorne tries to reveal the depth of the 'political' Puritan Culture and the significance of the 'sensuous' individual who stands against the culture to create new laws, remove the appearance, and let the reality illuminate various experiences. And in dramatizing this conflict he is quite assertive although Connolly (1970) and many others believe that Hawthorne never subscribed completely to the transcendental movement and was never satisfied with what they wished to achieve at Brook Farm.

The Scarlet Letter as an area of human experience shows the duality between appearance and reality differently from what may be seen in a Shakespearean work where one disguises himself or herself to test the love of another. Hawthorne talks about a culture in which the privileged group here the magistrates - define certain religious codes for people that, in appearance, seems to be to the people's benefit while, in reality, these codes are imposed so that the people are unified and as Fox (1991) believes they are "social individuals" (p. 104) and not individuals. The Puritan Culture knows that when individuality is gone, consciousness is gone too. Thus, people change to subjects and become like the products of a society that runs everything based on appearance to bind the members together and hide the truth. For a symbolic and moralistic writer like Hawthorne, a member carrying a secret sin can best be an expression of the conflict in the mind and heart of a character that gains a new identity by violating the codes and creates her own religion and rules of nature. What follows shows how the motif of appearance-versus-reality occurs in four binary sets of: Puritan Culture / Individual; Arthur Dimmesdale / Hester Prynne; Religion/

${ }^{1}$ Refer to Karl Marx's Early Writings (1851). 
Love; and Sable/Gules, the result of which is the creation of such coherence to run the final theme throughout the novel so that new lights are shed on the appearance-versus-reality technique employed by both the society to rule and keep as it is, and the individual to transform and construct anew.

\section{PURITAN CULTURE / INDIVIDUAL}

A jobless Hawthorne wrote The Scarlet Letter during a time which Connolly (1970) calls a "period of anguish and trial" (p. 12). The writer's anguish over the society marks the beginning of the struggle between community standards glorified by ministers, and individual values setting forth the primacy of class over individuality. In Hawthorne's New England every aspect of life is covered by laws haunting its people's imagination, putting on pious faces carrying some sort of guilt and, at home, they remove the unreal cover just to enjoy a moment's relief with real thoughts and feelings. The conflict between a free and spirited nature and a convention-based materialistic society is not new. In appearance the Puritan Culture stresses human nature common to all its members while in reality each individual is a unique self with personal desires to be fulfilled. Apparently the government injects the idea of union into the veins of people so much so even a slight movement against the grain may be regarded as taboo.

Stevenson (1990) in his article on Heinrich Boll's Billiards at Half Past Nine states the belief of the so-called Lambs: "There exists a higher bond than that of simple blood kinship, a bond based on a vision of the world as a necessarily moral realm in which brotherhood is established and maintained by shared values alone" (p. 104). For the so-called Beasts who hold power over the Lambs, he says that their "guise is order and respectability, the Beast is, in fact, moral chaos" (p. 105). This is what the Puritan society employs: in order to keep people away from truth, respectability and religion are put forward as guises that protect people from losing a higher reality. Accordingly strict Puritan codes are imposed on people the outcome of which is the difficulty in distinguishing between what is right and what is wrong, between appearance and reality. Little by little people believe in the righteousness of the system and lose the power to decide for themselves. 
Campbell (1997) in discussing 1984 states that the party's power depends on its ability to keep people ignorant of ... the truth. Without knowledge, people lack the information necessary for making choices in their lives. 1984 shows the destructive consequences of individuals surrendering responsibility for their decisions, opinions, and ideas to an outside group ... (p. 558).

If one dares "stand out from society ... [they] are often crushed by the system" (p. 808). This is when there exists no hope of reconciliation between the Puritan consciousness and natural instincts attributed to the self. By offering loyalty, respectability and hereafter joy as disguises and demanding sheer obedience from the members, the Puritan Culture imposes, in reality, a hegemony which, as Williams (1976) asserts, is "a lived system of meanings and values - constitutive and constituting - ...”; "taken for granted and real by people", and "a sense of absolute ... beyond which it is very difficult ... to move ..." and what the two symbolic figures - Hester and Dimmesdale - do is a symbolic violation of the absolute and a move beyond the apparent blessings (Webster, 1993, p. 62).

Therefore, the members of the society are subconsciously involved in abiding by the rules set reminding us of Althusser's "Ideological State Apparatuses" that are more effective than "Repressed State Apparatuses" (Webster, 1993, p. 59). Thus, people lose their freedom to feel, think, decide and act. The look from the authorities on individuals then becomes downward and we see them standing in a balcony above where Hester the symbol of individuality is located - the scaffold. Ipso facto the authorities by deriving individuals of the power to distinguish between appearance and reality mark themselves as sacrosanct models following whom leads to heaven, and hell awaits those who disobey. This is what the Puritan Culture knows by heart, for in The Scarlet Letter, we are faced with a crowd -"the crowd here is the whole of society" (Doren, 1966, p. 136) - coming from "an earlier time, broad shouldered, ruddy cheeked, firm of step .... They were a stern people ... repressive. They probably put the lid on more natural human impulses and emotions than any society before or since" (Salami, 1999, p. 444). The ruling class well aware of what has been put in the heart and mind of the crowd uses 'ideological apparatuses' to legally constitute laws for people, and ideology represents "a way of legitimating the power of the ruling class in society" (Webster, 1993, p. 59). When the apparently supported and proved conventions are institutionalized, then 
there remains no emotion or power of differentiating between the real and the apparently real. Weston (2002) believes that Puritanism "construct[s] a rigid, dualistic distinction between ... emotion and society" (p. 453). The outcome will be wearing happy faces and sad faces as the government dictates; those who choose a different attitude will meet punishment, which as the manifestation of the power of the ruling party, is itself a practice of law. Perhaps many members highlight the point that the Bible says that the onus of judgment falls into the Lord only. However, people of that time did not meticulously investigate the Bible as long as it supported their immediate and apparent needs.

Keeping such an extremely narrow view of the social standards was due to a culture coming from "a dark world where human injustice was done, but only because men fumbled in their understanding of justice ..." (Doren, 1966, p. 138). Culture as the product of the existing forces is effective enough to determine people's mind set and make them unvarying. Marx's (1968) words are worth quoting here: "It is not the consciousness of men that determines their being, but ... their social being that determines their consciousness" (p. 181). The Puritan Culture exposes its members to the good-versus-evil criterion, shapes their consciousness, and judges them accordingly while there allows no room for judging good and evil themselves. For the people who believe to be at this level, then life becomes a blessing in disguise. Individuals are then transformed into "subjects" who are "subject to the forces of control which operate in a given society" (Webster, 1993, p. 80). When Hester objects to Dimmesdale, she says: "And what hast thou to do with all these iron men, and their opinions? They have kept thy better part in bondage too long already!" (Harding, 1990, p. 197). "Iron men" which suggests restriction, convention and "iron doors of prison" stand in sharp contrast to the "roses" that have just sprang up before the prison suggesting birth and coming into existence of an individual possessing passion, making her own decision and letting her own "consciousness" determine her "social being."

By wearing the letter $A$, Hester loses her individuality and ironically adopts a new real one that stands against the apparent one just to sharpen the gap between what she really is and what she seems to be. As the "roses" are set against the "iron doors," the whole forest is put in opposition to the Market Place where everyone is having their false faces on. It is in the forest - source of evil from Puritans' point of view - that people are free to be themselves. For the Puritans it implies embracing, if not the truth, the 
reality of themselves. For the Puritans the forest is a place of evil and ironically it becomes a holy place for Hester and Dimmesdale: it is where they meet and "practice a holy feeling accompanied by beautiful and holy elements of nature" (Connolly, 1970, p. 15). The Puritan Culture is defined by the forest and the qualities it represents linking Hester with antiChristian values. In the forest Hester shapes her true and real individuality and gives, with a Jungian glance at the setting, rise to her unconscious ready to feel differently, and like the wilderness, challenges subjugation by her words. In a way Mistress Hibbins, practicing witchcraft, becomes another revolutionary figure by joining the witches and enjoying the freedom accorded to them. And above all "witches enjoyed a rare privilege in a society that buried so many things - the privilege of telling the truth" (Salami, 1999, p. 442): for, witchcraft was regarded as an evil practice just because of its freedom in revealing the real and rejecting the apparent truth.

\section{DIMMESDALE / HESTER}

"I must stand up in my pulpit, and meet so many eyes turned upward to my face, as if the light of heaven were beaming from it! ... and then look inward, and discern the black reality of what they idolize?" Dimmesdale continues that in "agony of heart" he has "laughed" at "the contrast between what I seem and what I am!" (Harding, 1990, p. 191).

It has been reported that Hawthorne was very much in favor of a character with a secret sin hidden in the depth of the heart. Hawthorne has explored the theme of appearance versus reality in his characters, mainly Dimmesdale and Hester, as bearers of a hidden guilt that has changed their lives significantly. What Hawthorne does is the exploration of Dimmesdale's character whose story is that of a "sensitive young man's initiation into sexuality with ill grace" (Salami, 1999, p. 438). Dimmesdale has, in appearance, a cloak on, which hides the reality of his sin and instead helps him wear an acceptable face. What burns him inside and in silence is taken to be the light of a celestial man standing before the mob. Dimmesdale is tortured by the guilt, for he is put in the center of the conflict between appearance - what he preaches - and reality - what he has committed. The anguish, the torture and the burden are so real to Dimmesdale that they give him "a real existence on this earth ..." (Harding, 1990, p. 191). 
The reader, who is allowed to be informed of Dimmesdale's complex thoughts and feelings, finds out that as a character supported by the magistrates, the mob, and Hester, he is caught between what he has committed and what he preaches not to be committed. Hester's lover with whom lies "the responsibility of this woman's soul" (p. 66) is torn between his love for her and his duty as a permanent member of the Puritan Culture that favors reason over passion and who can ignore his passionate nature? Not only has Hester experienced his passion but also the people have enjoyed his passionate sermons which mark Dimmesdale as a figure not in line with his colleagues. Dimmesdale is considered as "a miracle of holiness" and "the mouthpiece of Heaven's messages of wisdom" (p. 142).

When Dimmesdale rejects the offer of selecting a wife, it is regarded "as if priestly celibacy were one of his articles of church-discipline" (p. 125). As "victims of a passion so imbued with religious sentiment ... those virgins of his church grew pale around him ..." (p. 142). Dimmesdale's paleness is taken as the result of "too earnest devotion to study, his scrupulous fulfillment of parochial duty, and, more than all, by the fasts and vigils of which he made a frequent practice" (p. 120). It is even concluded that if he "were really going to die, it was cause enough, that the world was not worthy to be any longer trodden by his feet" (p. 120). And all of a sudden, to the reader's surprise, the real is put in front of the appearance when Pearl identifies him with the black man: "Is it the Black man?" (p. 187). Dimmesdale is a character who symbolically shows his rejection of Puritanical codes and becomes the representative of individual values and actually fulfills individualization by responding to the true feeling that aroused between him and Hester. The climax of his rejection of Puritanical codes and the desire to embrace reality is when he rejects Hester's offer of escape and instead reveals his true self by approaching the scaffold at night to show another letter $A$ red with the anger of true passion repressed and reality hidden for too long. Dimmesdale's change of mind is the hatred he shows towards Puritanism. This is obvious when Dimmesdale addresses Hester on the scaffold: "I charge thee to speak out the name of thy fellowsinner and fellow-sufferer! ... believe me, Hester, though he were to step down from a high place, and stand there beside thee on thy pedestal of shame, yet better were it so, than hide a guilty heart through life (p. 67).

This shows Dimmesdale's eagerness to reveal the truth and the reality of his innermost powerful feelings. As a matter of fact it has been a long time Dimmesdale had wanted to stand against the Puritanical codes, stress 
his distress towards the appearance, and defile man-made laws: "I should long ago have thrown off these garments of mock holiness, and have shown myself to mankind as they will see me at the judgment-seat" (p. 192). "Garments of mock holiness" are suggestive of the rules -religiousthat have nothing to do with what is holy and right and are mocking enough to be obeyed with no light of illumination. Dimmesdale's sermons are moving and poetic to mock the reason-bound and devoid-of-sentiment language of the ministers. The irony of a fearful hypocrite man making such sermons that make people cease to fear anything but the Lord, the Omniscient, Omnipotent God shows how paying-off the Puritan Culture has been and instrumental in blurring the boundary between apparent and real. Dimmesdale is forgiven and redeemed, for "his suffering makes him beautiful and because Hester continues to love him" (Doren, 1966, p. 133).

As many authors speak through their characters, many critics have, since 1850, debated the idea that Hawthorne is after justifying a prohibited sin and introducing Hester as a cult heroine seeking fulfillment in her union; or, that Hawthorne is depicting Hester responsible for her wrongdoing.

Hester, as a figure representative of fresh and striking views and nonconformities, may be a reminder of Hawthorn's interest in the American Transcendental Movement with its emphasis on the natural world and soul. Nevertheless, there is more to Hester's motives as well as potentialities of her nature. When it comes to the analysis of her motives, the reader is likely to refer to her love for Dimmesdale as the real motivation. In appearance she is a fallen woman, disloyal to Puritan-defined rules while in reality, enriched by Dimmesdale's love, she changes to a cult heroine loyal to the laws of her own nature taken as her "inner life" which in Ziff's words "can be more real than ... outer life" (Ziff, 1966, p. 124). And here we are presented with another outcast or renegade or whatever "trodden under all men's feet" (Harding, 1990, p. 118) who will be crushed for not being in line with the system. As a matter of fact, "the reference to William Hawthorne's infamous cruelty to the Quaker Ann Coleman anticipates the punishment of Hester ..." (p. 39). The female protagonist "is judged as a guilty harlot even though she is actually a loyal loving woman" (Campbell, 1997, p. 721). The differences in value and standards show the contrast between appearance and reality and "tremendous pressure against those who violate the laws of society" (p. 721). The pressure is so intense that it pushes Hester to a mental trauma and changes her to a renegade who 
breaks free of the Puritan rules to become the worshipper of the temple of her own nature. She cannot tolerate a society that will not allow her to reveal her true and real identity: an identity backed up with unique qualities that separate her from other passive and obedient members. The narrator is taken even by her physical beauty: "she had in her nature a rich, voluptuous, oriental characteristic, a taste for the gorgeously beautiful" (Harding, 1990, p. 83).

Now for such a beautiful, wild, passionate character, Chillingworth, who seems to be a devoted physician but who is a vengeful evil man, cannot be a proper counterpart. Hester, thinking of escaping with Dimmesdale is similar to Charlotte Bronte's Jane Eyre a passionate woman dubious about going off to France with Mr. Rochester with whom she is deeply in love. Dimmesdale and Mr. Rochester might, at the first glance, seem villains for having violated society-defined conventions. Suffering from their own particular weaknesses, the two of them seem to be Byronic heroes who are often "handsome, but like Lord Byron himself, who was lame, they may have a physical handicap that only increases their sex appeal" (Salami, 1999, p. 253). Moreover, both of them suffer from a sin or scandal that marks each one's past. The reader, having been given access to those levels of conscious and subconscious unknown to the world around, is likely to take side with them. All these two characters show is a saturnine front and appearance via which the reality of the experienced moment cannot be read. The Byronic hero is "an idealist" and the "sensitivity can only be revealed ... when he manages to find a superior woman who can understand his true nature" (Salami, 1999, p. 253). Hester and Dimmesdale, from a Puritanical point of view, appear as rebels however, as idealists, they are after defining their own religion, consummating it as saints who stand as threats to the society.

One matter of concern with regard to what Hester has done is whether she justifies it or not. Harding (1990) believes that "there is no suggestion that she believes her adulterous love is justified by its intensity or spontaneity" (p. xviii). However, she does not regret what she has done, for the best thing came out of it: Pearl, and of course "in giving her [Pearl] existence, a great law had been broken" (p. 91). Hester knows and morally accepts her sinful act and the judgment that follows showing no resentments or challenges to the power holders. In appearance Hester has reached the end for having an unforgivable sin but sin for her is a beginning; in fact, sin, with the weakening power it has, in the hands of 
Hawthorne, gives strength to Hester. It is through sin that Hester reaches experience just to enter the state of organized innocence where she can experience love and the one life running through all. And the coup-de-grass is inserted when Hawthorne shows how morally as well as emotionally Hester is developed and criticizes the religious codes defined by those who put a ban on the development of such symbolic relationships. The sin with the evil setting marks the beginning of Hester's ideal life and the revelation of her reality. The flourishing of her reality means the flourishing of her noble thoughts, deeds, and, by and all, her real personality which is hard not to sympathize with: "her breast with its badge of shame was but the softer pillow for the head that needed one. She was self-ordained a Sister of Mercy" (p. 161).

In opposing Romantic and Puritanical philosophies, Hawthorne puts the reality of the Romantic symbol and image of the revolt of imagination against the Puritanical cloaks that obscure the difference between the two. If The Scarlet Letter is regarded as a great romance, it is due to Hester whose feelings and sensations take on literary values in practicing a humanly act of love and rejecting a religion of fear for years through which she "has not consented to let her soul be killed" (Doren, 1966, p. 131). In the literal sense, Hawthorne tries to win the reader's sympathy for Hester who is in love with the Puritan minister and not with her husband. As a person in need of loving and being loved, Hester is excused for having such an affair that likens her to 1984's Winston Smith who, through a secret love affair, fought the system. In fact, Hester finds her own judgment as the real and true consultant and dares express her freedom of choice and idea that it is the individual feeling that is the most prominent and desirable reality that exists. It is the law of her heart that she abides by and knows to be real and deep. What makes an unforgettable character of Hester is that all she is and does and feels are accompanied by her obsession with guilt. Hester has a Puritanical conscience after all and cannot avoid the compelling hold of the community and the repressive urge of her natural instinct. Hester feels the burden of the past on her shoulders "but the fortune, because its outcome is contingent on action done, is the true moral realm" (Stevenson, 1990, p. 97). Hester does not leave the place of herguilt- Boston- and stays there to defend what she sincerely believes in. She-becomes the manifestation of the humanist view of the Renaissance period placed at the centre of the community. Accordingly she is "the individual as the source and end of ideas, action and meaning" with whom 
new outlooks appear and become meaningful (Harding, 1990, p. 79). She becomes the harbinger of a new religion in which affection is the first word to be loudly preached.

\section{RELIGION / LOVE}

Religion has always been one of those means by which governments have defined laws and have controlled their members. Many deviations have been put to religion and different objectives have been pursued accordingly. To this, Puritanism was not an exception. Many references in The Scarlet Letter clarify that "the role of the godly in the Puritan colony had economic and social implications" (Harding, 1990, p. 14) to the extent that the narrator says "religion and law were almost identical" (p. 50). As a matter of fact, religion acts as a proper guise for what the authorities wish to either impose or obtain and shape their rules accordingly. Although religion seems to shape morality, gradually it turns to chaos; though it may display apparent harmony and benefit, in reality it may hold disorder within and not even a soupcon of affection and love. Campbell (1997) believes that "genuine emotions like ... love ... define people as unique individuals ..." (p. 558). Godwin (1974) goes even further and puts "love to man" and "piety toward God" side by side stating that "religion is nothing, if it be not a sentiment and a feeling" (pp. 69-70).

In this sense, Hester appears to be more pious by practicing her true religion when she assures her town mates that "in Heaven's own time, a new truth would be revealed, in order to establish the whole relation between man and woman on a surer ground of mutual happiness" (Harding, 1990, p. 263). Hester's religion is not defined merely by reason. Feelings are the teachings of her school for which she has fought wholeheartedly. Weston (2002) in discussing 'Puritan Temper' refers to "true religion" as "characterized by pious and benevolent feelings" (p. 451). Hester finds it indispensable to devout herself to the secret hidden in her heart if she is to be a religious, pious woman. She has to practice what she believes in and preaches. She is loyal to reality and the laws of her nature set against Puritan-made rules. It is through her love affair that Hester claims a new identity, a real one, one different from what the public is acquainted with. She, also, claims a real identity for another follower of this new school, Dimmesdale. When she cries "God gave me the child!" (Harding, 1990, p. 113), she subconsciously identifies Dimmesdale, a 
member of the Puritan Culture, with God. Hester shows no respect for the world's law, for she knows a higher reality and truth than that practiced by the Puritans. This higher reality for Hester is love to which she remains loyal and with which she remains united. In the holy name of love she, as a cult heroine, stands up to a religion that appears merciful but is ugly and cruel to true love and affection. She stands up against a religion that has deprived her of her right to love and be loved. As a real religious and pious woman, Hester knows and believes that religion "must become a vital principle, it must affect the heart and act upon the passions, before it can greatly modify the character of man in society" (Godwin, 1974, p. 317), which means that her sin is rooted in the most perfect of all feelings: love, and the bitter irony shows how the Puritan Culture has been successful in obscuring the difference between appearance and reality and not successful in subjugating all its members.

Hester believes in the healing power of love and the changes it affords men. Hester's religion is that of heart and not head, and that affection brings joy. The narrator sees Hester as an "angel and apostle of the coming revelation ... lofty ... beautiful ... wise" who will arrive through "ethereal medium of joy" revealing "how sacred love should make us happy, by the truest test of a life successful to such an end!" (Harding, 1990, p. 263).

Bestowed with the power of love, Hester is able to change everything and show the reality of appearances. She is able to create a new identity, a real personal identity different from the apparent social one. The new identity is nourished through the feeling of love and her relationship with Dimmesdale.

Hester's self is empowered through sympathy and relationship with others. She becomes strong enough to change the implications of the scarlet letter she is doomed to wear, to fresh and novel implications.

\section{SABLE / GULES}

At last Hester bends the 'Sable' Puritanism to show the 'Gules' reality of her self. On Hester's slab appears "On a field, Sable, the letter A, Gules" (p. 264). Brant (1958) suggests that the last line of Marvell's The Unfortunate Lover may be a source for the saying: "Forced to live in Storms and Wars: / Yet dying leaves a perfume here, / And Musick within every Ear: / And he in story only rules, / In a Field Sable, a Lover Gules” (Harding, 1990, p. 293). 
What is noteworthy here is the opposition of black and red that appears as a color motif throughout the work adding to its thematic unity. Hawthorne has tried to portray a black culture which is willing to disguise its members' red feelings and passion in black. The symbolic black is attributed and enriched with dualistic qualities and the black by which Puritanism is meant to be different from the dark of night and the forest.

At the very beginning, the writer draws the reader's attention towards the prison and the "black rose-bush" having sprung up there and then the jailor who is "black, grim, ugly-eyed old man!" (Harding, 1990, p. 229) symbolizing the dark, macabre atmosphere of the setting. There, then, appears Governor Bellingham the "guard of honor" with "a black velvet tunic" (p. 64) with John Wilson, the eldest clergyman of Boston, at the center of focus looking like a "darkly engraved portrait" (p. 65), and even at the Market Place the narrator notices the "general tint" of "human life" as "sad grey ... or black" (p. 232). And the whole Puritanism with its ministers looks like "pine-trees, aged, black, and solemn" (p. 95).

The depiction of major scenes exhibits the black Puritanical mode of life and age. In such a black atmosphere and among the aged and withered spirits there appears Hester the defender of love, a critic of blind obedience, wearing the letter $A$ embroidered in red and shining like a jewel throwing "a lurid gleam along the dark passage-way of the interior" (p. 69). What Hester does is a symbolic, sincere attempt to remove herself and Dimmesdale out of the black framework of Puritanism in order to reveal her real and red thoughts and feelings. It is in chapter 17 that the narrator refers to the emotional openness of Hester and Dimmesdale as they are standing together "with the sanguine passion of hand clasped in hand" (p. 195). Hester's passionate nature is so sanguine that at the time of "pestilence" or "calamity," she appears in "the household that was darkened by trouble" with the red letter glimmering "with comfort in its unearthly ray" (p. 161). Indeed numerous references to the letter $A$ bestow unity upon the work. Any time Hester appears the letter $A$ is there on her breast, each time suggesting an implication. The letter $A$ is hardly recognizable for the reader to stand for a definite indisputable image or fixed signifier. The sexton refers to "a great red letter in the sky" (p. 158), and the meteor makes a dome-like shape, "the letter A, --marked out in lines of dull red light,--" (p. 155) in the black sky. The appearance of comets may predict the destruction of tyrants and the termination of rulers: an end Hester and the letter A may suggest to the community. Hester, who is literally and 
figuratively red in a black culture, is similar to the golden-embroidered letter in the middle of the rough material she has on. She was doomed to wear it, for the criminal's body had to show the sentence and in Foucault's words the sentence has to be "legible for all" (p. 43). The letter, as a signifier, signifies Hester's rebellion against 'sable' conventions and she is judged by the letter $A$ on her heart and not by the letter of passion in her chest which makes it difficult to distinguish between the appearance and reality of the letter. Hester is seen as wearing the letter $A$; however, no one notices the priests wearing the letter $C$, suggestive of, perhaps, Cruel or $S$ for Sanctimonious.

The letter $A$ demands an imaginative power to interpret the reality. It is not easy to take $A$ as the initial letter of 'Adulteress.' In appearance it may be so however, other implications help to bring other suggestions to the mind. Hawthorne in Endicott and the Red Cross (1837) has written about the embroidered "fatal token" he had in mind to mean "Admirable, or anything rather than Adulteress" (Doren, 1966, p. 130). People eventually misread the letter and do not associate Adulteress for the letter $A$ which is a signification of the fact that they also subvert the Puritan-defined system of laws as if defined by God. So the letter $A$ does not attract the world's anger but it is something "to be sorrowed over, and looked upon with awe, yet with reverence too" (Harding, 1990, p. 263).The sexton notices "a great red letter in the sky, --the letter $A$, -- which we interpret to stand for Angel" (p. 158), and even Harding (1990) believes that the narration is in step with the "strategy of subversion," for "the narrative ... undermines the stability of the system of signs by which the values of the Puritan theocracy are maintained" (p. 21). Thus A can stand for Angel or Able. It may stand for Arthur - Hester's lover - or Alone - in such a society - or Against - such a culture - or Affection - Hester's religion - or Anew - building a new life and religion. Hester is Alone in the world "as to my dependence on society, and with little Pearl to be guided and protected, - alone, ..." (p. 164). People conclude, "it meant Able; so strong was Hester Prynne, with a woman's strength" (p. 161). If Christianity is a religion of love, then Hester is a real Apostle spreading the teachings of Christ in that Puritanical environment. Besides, the letter with the effect of a cross gives the wearer a kind of sacredness like a "nun" (p. 163) connecting Hester and the Virgin Mary.

$A$ as the first letter of alphabet may suggest a beginning, perhaps the beginning of a new life after putting the letter on. A new life awaits Hester 
after flaunting a long-held tradition of Puritan Culture. The token for many had come to mean "her [Hester's] many good deeds since" (p. 162). Hester constructs her life through helping others and keeping alive the letter $A$ suggesting the red light of deep love in the dark sky of Puritanism. Here Hester's strength in transfiguring the signifier $A$ is of paramount significance. Hester is able to transform the meaning from appearance and what it appears to be, to the reality of it by subverting the Puritan connotations of such symbols.

What the "society would make into a stigma of shame, Hester converts into a thing of beauty, just as she converts the living symbol of the letter $A$, Pearl, into a thing of beauty by her elegant dress" (Connolly, 1970, p. 14). By refusing to let her scarlet letter be removed, she symbolically remains loyal to her lover - Arthur - and her real identity as Able and Angel and becomes "a living sermon Against [emphasis mine] sin" (Harding, 1990, p. 63) of hiding the truth and making people put on false faces and be good and loyal members in appearance.

As a writer interested in the secret sins people may carry in their hearts, Hawthorne explores the implications of a secret act of a soul in New England, Boston. Hawthorne presents the reader with the Puritan Culture with all the apparatuses the system employs in order to subjugate its members and hide the truth.

Hawthorne's social, moral, and religious milieu provided him with raw materials which went into this superb literary piece that is the story of two characters living with the weight of what they have done and what follows. The novel puts forward the everlasting conflict between the society and the individual. What is novel and eye-catching is the recurrent theme of appearance versus reality woven into different elements of the novel all throughout. Man's individuality has always been threatened and in some cases stifled by convention which is disguised in varied forms such as religion, family, society-defined rules, and particular social, political, economical codes. Rejection of each can be taken as the assertion of a new reality and identity, the eruption of which threatens the foundations of priesthood or whatever is hidden under the cloak and appearance of morality.

As a matter of fact, it is the very theme of appearance versus reality by which Hawthorne presents a symbolic figure with a symbolic violation of the society-defined rules and the unexpected consequences. That is what makes readers lack consensus about the final meaning and interpretation of the characters and events. 


\section{CONCLUSION}

The Scarlet Letter is not only about good and evil but appearance and reality, a theme practiced all throughout the novel. As it is stated at the end of the novel, "no man, for any considerable period, can wear one face to himself, and another to the multitude, without finally getting bewildered as to which may be the true" (p. 216). Dimmesdale and Hester are judged based on appearance, and a gradual revelation of their reality marks them as adversaries to those who want to blur the difference between appearance and reality. The narrator, in the concluding chapter, cries "Be true! Be true! Show freely to the world, if not your worst, yet some trait whereby the worst may be inferred!" (p. 260) to show how the Puritan Culture provides the characters with a setting where "the secret acts of the soul are matters of public concern, in which the [symbolic act of] adultery is a crime against the state," (Ziff, 1966, p. 126) and ironically the letter A must be worn to make the secret public, and therefore to intensify the confusion. However, Hester's religion is one of love and affection and with the power she is bestowed, she subverts Puritanical significations to create new ones and therefore takes refuge in her heart to gain more power from the scarlet letter and reject the 'sable' culture. Hawthorne shows the reality of the token, what in appearance is a "scorching stigma" (Harding, 1990, p. 247) while in reality and by Hester has changed to a badge of courage, affection and ability.

Hester's lover also has the brand of sin on his heart and as a violator of the Puritanical codes makes the reality known to all that we are all sinners, yet some are disguised in cloaks as law makers and gods. Hester reveals the fact that under every 'Gules' letter, there lie much deeper meanings than what the 'Sable' culture tries to uphold.

\section{REFERENCES}

Campbell, W. J. (1997). The book of great books: A guide to 100 world classics. New York: Wonderland Press.

Connolly, T. E. (1970). The scarlet letter and other tales. New York: Penguin Books.

Doren, M. V. (1966). The scarlet letter. In A. N. Kaul (Ed.), Hawthorne: A collection of critical essays (pp. 129-141). New York: Prentice-Hall. 
Fox, R. (1991). The novel and the people. London: Commonwealth Publishers.

Godwin, W. (1974). Life of Chaucer ( $2^{\text {nd }}$ ed.). New York: AMS Press.

Harding, B. (1990). The scarlet letter. Oxford: Oxford University Press.

Marx, K. (1968). Preface to A contribution to the critique of political economy. London: Lawrence and Wishart.

(1975). Early writings. (R. Livingstone, Trans.). Harmondsworth: Penguin Books. (Original work published 1851).

Salami, I. (Ed.). (1999). Study of thirty great novels. Tehran: Mehrandish Books.

Stevenson, D. (1990). The temporal-moral matrix of Heinrich Boll's billiards at half-past nine. $20^{\text {th }}$ Century Literature, 36(1), 95-113.

Webster, R. (1993). Studying literary theory. London: Hodder Headline Group.

Weston, R. (2002). Politics, passion and the 'Puritan temper': Godwin's critique of Enlightened Modernity. Studies in Romanticism, 41(3), 448-469.

Williams, R. (1976). Keywords. London: Fontana.

Ziff, L. (1966). The ethical dimension of "The Custom House." In A. N. Kaul (Ed.), Hawthorne: A collection of critical essays (pp. 123-129). New York: Prentice-Hall. 